\title{
Pseudomonas stutzeri
}

National Cancer Institute

\section{Source}

National Cancer Institute. Pseudomonas stutzeri. NCI Thesaurus. Code C86706.

A species of aerobic, Gram negative, rod shaped bacteria in the phylum Proteobacteria.

This species is motile, non spore forming, catalase and oxidase positive and is able to convert nitrates to nitrogen gas. P. stutzeri is an opportunistic pathogen. 